\title{
Duodenal Ulcus Perforation: An Unusual Cause of Acute Abdomen in Pediatrics
}

\section{Çocuklarda Nadir Görülen Bir Akut Karın Nedeni: Duodenal Ülser Perforasyonu}

\author{
Fatma Saraç1, Kamil Şahin2, Adem Duru3, Ayşe Saygılı4 \\ ${ }^{1}$ Haseki Training and Research Hospital, Clinic of Pediatric Surgery, Istanbul, Turkey \\ 2 Haseki Training and Research Hospital, Clinic of Pediatrics, Istanbul, Turkey \\ 3 Haseki Training and Research Hospital, Clinic of General Surgery, Istanbul, Turkey \\ ${ }^{4}$ Okmeydanı Training and Research Hospital, Clinic of Pediatrics, Istanbul, Turkey
}

\begin{abstract}
Since the perforation of duodenal ulcer is a less frequently seen condition in children, it is considered as one of the final possibilities in the list of differential diagnoses of acute abdomen. In our study we presented a 16-year-old patient who suffered from abdominal pain, vomiting, and diarrhea after eating a Turkish special, sliced chicken meat, which predominantly suggested food intoxication. However, during his follow-up, manifestations of acute abdomen necessitated abdominal exploration which revealed duodenal perforation. We performed a successful implantation of omental patch (Graham patch), and simple closure on the patient, and he was discharged without any postoperative sequela.

Key Words: Duodenal ulcus perforation, peptic ulcus disease, pediatrics
\end{abstract}

ÖZET

Duodenal ülser perforasyonu çocuklarda az görülen bir durumdur. Bu nedenle akut batının ayıııcı tanıları arasında son sıralardadır. Biz de bu çalışmamızda 16 yaşında, tavuk döner yeme sonrası başlayan karın ağrısı, kusma, ishal nedeniyle ön planda besin intoksikasyonu düşüülen ancak takiplerinde akut batın tablosu gelişmesi üzerine opere edilen ve doudenum perforasyonu saptanan hastamızı sunduk. Hastamıza omental patch ile primer kapama (Graham patch) yöntemi ile başarlı bir şekilde cerrahi müdahale yapılıp, postoperatif sekelsiz olarak hastanemizden taburcu edilmiştir.

Anahtar Kelimeler: Duodenal perforasyon, peptik ülser hastalı̆ı̆, çocuk

\section{Introduction}

Although the incidence of peptic ulcer disease in children is lower than that seen in adults, in recent years an increase in its incidence has been observed compared to previous years. Almost all pediatric cases of peptic ulcer are located in the duodenum. Gastric ulcers are very rarely seen. Peptic ulcer disease divides into two categorieas as primary, and secondary ulcers. Most of the cases with primary duodenal ulcers are related to Helicobacter pylori infection. Predisposing factors such as serious stressful conditions, systemic diseases, head traumas, burns, surgical interventions, and drug use (NSAIDs) accompany secondary duodenal ulcers (1-4).

Duodenal ulcer disease is not seen frequently in children. Therefore, diagnosis can not be generally made before the development of complications such as bleeding and perforation. Even sometimes, as was seen in our patient, diagnosis is made during laparotomy $(1,2,5,6)$. 


\section{Case Report}

A 16-year-old male patient applied to our pediatric emergency polyclinic with complaints of abdominal pain, vomiting, and diarrhea a few hours after eating a Turkish specialty, sliced chicken meat. Predominantly the case was evaluated as food intoxication, and monitored in the observation room. His biochemical parametres at admission were as follows: leucocytes: 11.15 109/ UL (neutrophils: 42.4\%, lymphocytes: 47.5\%), CRP: $1.37 \mathrm{mg} / \mathrm{L}, \mathrm{Hb}: 14 \mathrm{~g} /$ dL, Htc: 43.3\%, plt: 405 109/uL Na: 137mEq/L K: 4.05 $\mathrm{mmol} / \mathrm{L}, \mathrm{Cl}: 103.8 \mathrm{mmol} / \mathrm{L}, \mathrm{SGOT}: 22 \mathrm{U} / \mathrm{L}, \mathrm{SGPT}: 15 \mathrm{U} / \mathrm{L}$, BUN: $29.8 \mathrm{mg} / \mathrm{dl}$, and creatinin: $0.84 \mathrm{mg} / \mathrm{dl}$. Plain abdominal graphy demonstrated a few intestinal air-fluid levels. Subdiaphragmatic free air was not detected.

His abdominal ultrasound (US) detected considerable amounts of free fluid between intestinal loops in the lower abdominal quadrants, and minimal amounts of free fluid were also observed below the spleen, and between the liver and the duodenum.

The patient was referred to the pediatric emergency polyclinic in consideration of biochemical test, physical, and radiological examination results, which revealed whole abdominal tenderness, guarding, and rebound tenderness being more prominent in the lower right abdominal quadrant. Personal, and family history of the patient was unremarkable.

The patient with manifestations of acute abdomen was primarily thought to have perforated appendicitis, and was operated on. Through classical McBurney incision, abdominal cavity was entered. Intraabdominal exploration demonstrated presence of diffuse pus, and free fluid in the abdominal cavity. All bowels were coated with false membranes. Caecum, and appendix were apparently edematous, and inflamed. After ligation of the appendiceal mesentery, appendectomy was performed, and we proceeded with exploration which revealed an area of perforation measuring nearly $1 \mathrm{~cm}$ anterior to the duodenum. Since it could not be reached through McBurney incision, duodenum was approached, and explored via supraumbilical median incision. The perforated area was covered with omentum, and closed with interrupted sutures. Abdominal cavity was irrigated with warm physiologic saline solution, and two drains were placed both in the subhepatic area, and Douglas recess. Then the layers were closed respecting their anatomic planes.

During the postoperative follow-up period the patient's condition was stable, and he received antibiotherapy, and gastroprotective medications. On the $4^{\text {th }}$ postoperative day his nasogastric tube was clamped, and he started to consume oral fluids. On the $6^{\text {th }}$ postoperative day, his drains were removed, and he was discharged without any complication with oral antibiotherapy, and proton pump therapy.

\section{Discussion}

Since peptic ulcer disease is not seen very frequently in the pediatric age group, it does not very often come to one's mind among the causes of abdominal pain occurring in children, and diagnosis can be made only after the emergence of complication(s). Although formation of acid, and pepsin are the most important factors in the development of peptic ulcer, serious stress, Helicobacter pylori, familial predisposition, systemic diseases, burn wounds, head trauma, and drug release (NSAIDs, and steroids) also play critical roles $(1,2,6)$.

Peptic ulcer disease is classified based on its etiology as primary, and secondary, and according to its location as gastric, and duodenal ulcer disease. In patients aged less than 10 years, secondary type localized in the duodenum is frequently seen. However in patients $\geq 10$ years of age, primary ulcer disease is more prevalent. Primary duodenal ulcer is associated with H.pylori infection. Secondary ulcer disease is linked with external predisposing factors such as medications, trauma, surgery, and stress $(1-3,5,7)$.

Duodenal perforation is one of the causes of acute abdomen. In case of suspicion, it is easy to make a diagnosis of peptic ulcer perforation. Sudden onset of abdominal pain, generalized peritonitis, wooden abdomen are patognomonic signs of peptic ulcer perforation. In nearly $90 \%$ of the patients subdiaphragmatic free air is detected (3). In a study by Hua et al., the authors revealed subdiaphragmatic free air in $82.7 \%$ of their patients (8). In a study presented by Ndour et al. (9) the researchers disclosed duodenal $(n=3)$, and gastric $(n=1)$ perforations in 4 patients with gastroduodenal perforation, and observed subdiaphragmatic free air in 3 patients. Wilson et al. (7) demonstrated the presence of subdiaphragmatic free air in a 7-year-old patient with duodenal perforation who presented with symptoms of gastroenteritis. Yadav et al. (2) revealed the presence of duodenal perforation in a 6.5-year-old case with thalassemia major under deferasirox therapy. Mbarushimana et al. (10) reported a patient who consulted them with complaints of lower abdominal pain, and vomiting lasting for 4 hours. The patient's radiograms revealed subdiaphragmatic free air which necessitated surgical exploration with resultant disclosure of duodenal ulcer perforation. However occasionally, radiograms can not demonstrate the presence of free air. In a case report presented by Lee et al. (5), free air could not be observed on plain upright abdominal radiograms of a 30-month-old baby boy brought in with symptoms of hematochesia. However, his surgical exploration revealed that the wall of the gallbladder had masked the perforated area.

Our patient had complaints of abdominal pain with a sudden onset, vomiting, and diarrhea which had started a few hours previously. Immediately before the onset of his complaints he had eaten a Turkish specialty, sliced chicken meat, so at the beginning we thought of food intoxication. He didn't have any history of peptic ulcer disease. None of the predisposing factors were present. His plain abdominal radiograms did not reveal the presence of subdiaphragmatic free air. His existing acute abdominal manifestations, and presence of free fluid in the lower abdominal quadrant as detected on US, made us think prominently of perforated appendicitis, and he was brought into the operating room. 
Diagnosis of duodenal perforation could be made only during laparatomy. Even though H.pylori was not detected, the case was accepted as primary peptic ulcer, and triple treatment was administered for the eradication of H.pylori.

Surgical treatment of peptic ulcer perforation changes with the severity, and extent of the perforation. Most cases with perforation can be treated with simple closure with omental patch. For complex or larger perforations, definitive operations including vagotomy or gastric resection can be required $(3,6)$. In our patient, the perforated area was closed with Graham patch, and postoperative improvement progressed without any problems.

In conclusion, even though peptic ulcer perforation is not seen very frequently in pediatric population, in adolescents with findings of acute abdominal pain, and peritoneal irritation, one must entertain high degree of suspicion about the possible presence of peptic ulcer, and surgical intervention should be performed without delay.

Informed Consent: Consent form was filled out by all participants, Concept: Fatma Saraç, Kamil Şahin, Adem Duru, Design: Fatma Saraç, Kamil Şahin, Ayşe Saygll, Data Collection or Processing: Fatma Saraç, Kamil Şahin, Adem Duru, Analysis or Interpretation: Fatma Saraç, Kamil Şahin, Adem Duru, Ayşe Saygllı, Literature Search: Fatma Saraç, Ayşe Saygllı, Writing: Fatma Saraç, Ayşe Saygllı, Peer-review: External and Internal peer-reviewed, Conflict of Interest: No conflict of interest was declared by the authors, Financial Disclosure: The authors declared that this study has received no financial support.

\section{References}

1. Goldman N, Punguyire D, Osei-Kwakye K, Baiden F. Duodenal perforation in a 12-month old child with severe malaria. Pan Afr Med J 2012; 12:1.

2. Yadav SK, Gupta V, El Kohly A, Al Fadhli W. Perforated duodenal ulcer: a rare complication of deferasirox in children. Indian J Pharmacol 2013; 45:293-4.

3. Yildiz T, Ilce HT, Ceran C, Ilce Z. Simple patch closure for perforated peptic ulcer in children followed by helicobacter pylori eradication. Pak J Med Sci 2014; 30:493-6.

4. Yadav RP, Agrawal CS, Gupta RK, Rajbansi S, Bajracharya A, Adhikary S. Perforated duodenal ulcer in a young child: an uncommon condition. JNMA J Nepal Med Assoc 2009; 48:165-7.

5. Lee NM, Yun SW, Chae SA, Yoo BH, Cha SJ, Kuak BK. Perforated duodenal ulcer presenting with massive hematochezia in a 30-month-old child. World J Gastroenterol 2009;15:4853-5.

6. Kadian YS, Rattan KN, Malik A. Perforated duodenal ulcer a rare cause of acute abdomen in infancy: a report of two cases. Afr J Paediatr Surg 2008; 5:46-7.

7. Wilson JM, Darby CR. Perforated duodenal ulcer: an unusual complication of gastroenteritis. Arch Dis Child 1990; 65:9901.

8. Hua MC, Kong MS, Lai MW, Luo CC. Perforated peptic ulcer in children: a 20-year experience. J Pediatr Gastroenterol Nutr 2007; 45:71-4.

9. Ndour O, Bansouda J, Fall AF, et al. Peritonitis following gastroduodenal ulcer perforation disease in children: report of 4 cases. Arch Pediatr 2012; 19:1065-9.

10. Mbarushimana S, Morris-Stiff G, Thomas G. Atypical presentation of perforated peptic ulcer disease in a 12-yearold boy. BMJ Case Rep 2014; doi:10.1136/bcr-2014-204716 